Open Access

\title{
The social bases of a committed labor force: how guanxi works in the Chinese factories?
}

\author{
Yan Zhule
}

\author{
Correspondence: syy19811231@ \\ gmail.com \\ Institute of Sociology, Shanghai \\ Academy of Social Sciences, Rm. \\ 542, 622/7 Mid-Huaihai Rd, \\ Shanghai 100872, People's Republic \\ of China
}

\begin{abstract}
Existing research points out that social relations are crucial in governing employment relations and eliciting commitment but fails to clarify how they work in different contexts. Using an employer-employee nested dataset and interview records in the Yangtze Delta, this study addresses the effect of employer-employee native-place ties on employees' organizational commitment and how the effect is moderated by a firm's internal labor market. This study finds that native-place ties can enhance employees' organizational commitment, especially when the ties are stronger and constructed at a higher level. The firm's internal labor market functions as an effective moderating variable: when the internal labor market becomes more open and provides more upward opportunity for its employees, native-place ties become less effective in promoting organizational commitment.
\end{abstract}

Keywords: Employer-employee native-place ties, Internal labor market, Organizational commitment

\section{Background}

How can employers effectively elicit commitment from their employees? Why are some bosses able to secure effort while others fail to do so and, even worse, occasionally suffer from high voluntary turnover and sustained workplace shirking? Various research works have addressed this issue, among which the argument of "social embeddedness" is theoretically influential. Economic sociology and new institutionalism emphasize that pervasive social relations in the workplace often embed formally written contracts, rules, and regulations in a set of informal norms and perceptions that accordingly define each party's role and obligations. They thus strongly shape employees' commitment and obedience (Baron 1988; Granovetter 1974, 1992).

Chinese factories are filled with all types of social ties among the personnel, mainly primary ties based on lineage, kinship, and native-place origin. Urbanization facilitates vast migration from rural areas. Unlike what modernization theory predicts, rural-tourban migration has not significantly weakened or replaced traditional social ties. On the contrary, the unfamiliar and often hostile urban environment maintains and even reinforces the role of primary ties for migrants (Ma and Xiang 1998). These ties have been brought into the workplace and profoundly shape the nature of employment relations for the new working class $^{1}$ (Wen and Zhou 2007).

(c) The Author(s). 2018 Open Access This article is distributed under the terms of the Creative Commons Attribution 4.0 International License (http://creativecommons.org/licenses/by/4.0/), which permits unrestricted use, distribution, and reproduction in any medium provided you give appropriate credit to the original author(s) and the source, provide a link to the Creative Commons license, and indicate if changes were made. 
Although the subject of social embeddedness in employment relations has garnered wide scholarly attention, the literature suffers from at least two deficiencies. First, it is empirically controversial whether employer-employee social ties facilitate effective management in organizations with lower costs or hinder workers' efforts by somehow invalidating formal regulations and behavior controls. Second, few researchers have seriously discussed why social ties ultimately work and in which contexts their effect varies.

This research studies the role of social relations in shaping workers' organizational commitment, focusing on a typical type of social tie, the native-place tie between employer/ manager and their employees. Using employer-employee nested data collected from over 280 manufactories in the Yangtze Delta Region and semi-structured interviews with factory owners, managers, and ordinary workers, we argue that (1) to some extent, the native-place ties between employer and employees can promote employees' commitment, especially when the ties are strong and constructed at the higher level since employees usually expect higher returns when they share native-place origin with their superintendents; (2) the effect of such relations can be partially substituted if employees can secure equivalent returns from an alternative opportunity structure; and (3) the organization's internal labor market provides important alternatives for employees. When the employees expect resources and opportunity from the firm's internal labor market, they are naturally less dependent on and less constrained by the social ties with their employers. Therefore, the internal labor market moderates and constrains the role of social relations.

\section{Two bodies of literature on employment relations}

Since the inception of employment relations theory, two rather distinct bodies of literature have gradually evolved on workplace control and incentive structure. One views formal institutions as vital to establishing hierarchical order within organizations. Referred to as classical management theory and pioneered by Frederick Taylor and his disciples, it argues that through designing incentive systems, grievance and dispute resolution mechanisms, and appropriate rewards and punishments, "self-interested and intrinsically unmotivated employees will find it in their own interest to work toward the organization's goals, ... [and shape] subordinate behavior" (Miller 1992, 1). This point of view has been tremendously influenced by Max Weber's theory of rationalization (Hill 1981), which emphasizes that running an organization and managing human resources are a mechanistic problem in nature. To achieve effectiveness, one needs to prioritize efficiency in management, define and schedule work tasks and processes as clearly as possible, and break tasks down into the smallest possible units. Therefore, this organization usually embraces a highly centralized authority structure, eliminates work autonomy in every segment, and simplifies and streamlines operations (Taylor 1997/1911; Guillen 1994). What drives workers to obey? It is usually believed that direct monetary incentive plays an essential role in shaping a domination and compliance system. As Weber points out, "In the capitalist system, the most immediate bases of willingness to work are opportunities for high piece-rate earnings and the danger of dismissal" (Weber 1978, 151).

This literature contrasts sharply with the second view of employment relations that centers primarily on economic sociology and new institutional organizational study. It argues that all formal arrangements are socially embedded in a web of informal relations, which seriously constrains the effect of formal institutions. As behavioral scientists argue, an organization is often "organic" in that the interaction among members is not presumed by 
formal regulations in a mechanical way. Employers and employees have their own understanding of the legitimacy of the rules, and in the workplace, they usually want to sustain their relations with co-workers despite employers' efforts to break work tasks into small parts. Pervasive personal relations, small-group interaction, and nonmaterial needs all have a profound impact on employment relations and shape "group dynamism" to preserve order in the organizational hierarchy.

These works largely derive from the renowned "Hawthorne Experiment" ${ }^{2}$ dating back to the 1920s. In a Durkheimian tone, researchers argue that human beings like to be integrated into a certain group. The workers' urge to have adequate social interrelations with other people even dominates their desire for material gains. The rapid development of the industry often tears small groups apart, atomizes individual workers, and eventually ignites industrial conflict. Mayo argues that if industrial society cannot come up with new methods of social integration and comradeship to replace traditional community-based support, social maladjustment and social disorganization will very likely occur (Mayo 2003/1933). In "China Enter the Machine Age", Mayo's Chinese disciple, Kuo-heng Shih, observed that rural migrants often encountered indifferent managers and rigid administrative procedures in urban factories. Their traditional social ties were easily dissolved, which gave rise to shirking and labor turnover (Shih 1944).

As a negation to classical management theory, this literature emphasizes the role of informal institutions in the workplace. They criticize the fact that the economic efficiency mentality long dominated the so-called scientific management practices without acknowledging workers' need for adequate communication and socialization while at work. Managers try to maintain some level of collaboration by decomposing the labor process and creating interdependency among workers, but their efforts prove to be futile in the Hawthorne Experiments. As researchers eventually determined, the result is not discipline and collaboration but disorder and resistance since social participation is excluded from the organization and fatigue is widespread (Mayo 2003/1933).

If we regard labor management practices in the organization as a natural operation of a "contract," the above two groups of literature diverge on whether the contract is coordinated through a price mechanism or through a somehow authoritarian hierarchy. Those who follow Taylor usually argue that labor management operates as if in a pure market, in which the price mechanism is largely effective. Traded parties engage in a repeated game and usually resort to damage compensation claims, refusal to collaborate further, or an immediate exit when facing potential betrayal. This view assumes that an employment contract is normally based on voluntary commitment from both sides that face pressure from market competition and seek to optimize their gains. They constantly adjust to market demand and supply and, through a series of bargaining processes and transactions, finally reach equilibrium and efficiency. Although aware of the fact that trading labor usually differs from trading other commodities, which to some extent requires much more sincere commitment, this literature largely relies on formal institutions, such as economic incentive structures, formal legislation, and grievance procedures, to define people's entitlements, solve agency problems, and mitigate opportunistic behavior (Katzenstein 1985; Goldthorpe and McKnight 2006; Mühlau and Lindenberg 2003).

In contrast, for those who view employment contracts as intrinsically authoritarian, effectively enforcing a contract largely relies on its perceived legitimacy rather than paid price. As Ronald Coase points out, "The operation of a market costs something and by forming an 
organization and allowing some authority (an 'entrepreneur' to direct the resources), certain marketing costs are saved" (Coase 1937, 392). Unlike markets, authoritarian hierarchies often allow entrepreneurs to direct and institutionalize long-term mutual commitment so that the trade parties can trade off social acceptance and esteem against wealth (Miller 1992). They correctly note that the noncontractual elements, such as social and psychological connections between employers and employees, are powerful independent determinants of employees' organizational commitment and often profoundly influence their assessment of the legitimacy, equity, and humaneness associated with the employment contract (Baron 1988). When employees perceive the incentives and controls as inappropriate and thus lacking in legitimacy, these formal arrangements will not induce effort and commitment from the workers and, even worse, will likely reduce enthusiasm at work. ${ }^{3}$

Several empirical studies support the second view. A classic study of the Tennessee Valley Administration (TVA) finds that the personal networks and small cliques within the organization usually constrain the function of formal rules (Selznick 1949), sometimes even producing what Merton (1936) calls a "dysfunctional effect." French sociologist Claudette Lafaye argues in his Sociologie des Organisations that in the rationalization process, the new adopted regulations are often incompatible with the existing prevalent norms. While formal and informal rules often have different sources of legitimacy, the coexistence of these two types easily produces tension. The informal norms by no means disappear naturally; instead, they usually continue in every possible way and distort the role of formal institutions (Lafaye 2000). Crozier (2010) also illustrates this point that the bureaucracy tends to design an ever-increasingly complex labor process and labor management practices including hiring, supervision, performance review, and promotion. However, personal relations within the organization do not fade away in this process; on the contrary, the complexity of formal rules usually reinforces private exchange and interpersonal dependency since the rigidity of formal regulations increases uncertainty in daily interactions.

Situations in emerging markets are quite similar. On one hand, the "formalization" of employment relations has not yet squeezed out traditional social ties, as modernization theory has long anticipated. On the other hand, the traditional ties play a new role in maintaining discipline and order in the workplace. Arrighi's fieldwork in Rhodesia finds that many laborers still work part-time as farmers. They acquire their living necessities and accomplish labor reproduction through agriculture and are thus willing to accept relatively low wages and social insurance (Arrighi 1970). Burawoy reaches a similar conclusion when comparing miners in South Africa and California. If owners hire these migratory laborers, labor costs can be reduced tremendously since they can rely on primary social ties for labor reproduction and daily support (Burawoy 1976). A study of Shanghai workers in the early twentieth century reveals that the presumed solidarity among workers was never achieved since they varied greatly in skill level, birthplace, work situation, seniority, and gender. Perry even argues that the emerging capitalism in then-China was "more dependent on events in the countryside than on the direction of the Shanghai labor movement" (Perry 1993, 129).

An attempt to institutionalize employment relations is unfolding in contemporary China. Nevertheless, researchers still witness an emerging market with a huge number of "institutional holes." The new laws and regulations cannot be effectively and efficiently enforced and thus suffer from a crisis of trust and pervasive opportunism (Bian 2002; Zhu and Warner 2000). Uncertainty and risks deriving from institutional holes pose particular 
challenges for the transition in employment relations, and noncontractual elements in enforcing labor contracts will presumably continue for a long time.

This study is largely in line with economic sociology, arguing that the labor contract is coordinated through an authoritarian hierarchy rather than a pure pricing mechanism and that the social ties between employer and employees play a vital role in establishing, maintaining, and enforcing an effective contract. However, as Portes (2010) points out, affirming that market transactors behave in particular ways because of their "social embeddedness" cannot advance our understanding in any way. We need more proximate explanatory mechanisms. Thus, we need to go further by probing into the constraints and conditions of the working of social ties and discuss whether the effect of guanxi varies in different contexts.

\section{Do social ties elicit convenience for management?}

When the employer shares some social relations with his/her employees, does it have any impact on the employees' organizational commitment? Does this make it any easier for the employer to manage their labor force? Researchers have different answers regarding this issue. Some argue that employer-employee social relations definitely enhance employees' compliance and commitment, mitigate disputes and disobedience, and thus bring convenience to management. The fact that the employer hires someone who is loyal to them and who has personal information about the firm reduces "the chance of separation by making unlikely gross mismatches due to ignorance" (Granovetter 1992, 245) and lowers the possibility of conflict in the workplace (Streeck 2005, 256). Social ties are particularly useful in an environment with a higher level of cultural heterogeneity. Studies on ethnic entrepreneurs show that, facing market uncertainty, they usually require a labor force that is flexible as well as stable. A common way to achieve this is to hire relatives and from one's co-ethnic group to transform bureaucratic control into kinship-based fidelity (Waldinger et al. 1990, 413-416). Thus, the existence of cultural commonalities and social ties will generate trust and feelings of "jointness," which elicits consensus in employment relations (Aldrich and Waldinger 1990; Waldinger 1993). As Granovetter finds in Getting a Job, among those respondents who used contacts, $33.1 \%$ indicated that the contact was the new employer him/herself, while 19.9\% described this knowledge as resulting from a relation as a "business friend of the employer" (Granovetter 1974, 46).

China is no exception to this situation. Analyzing the employment of kin in Hong Kong-invested factories in mainland China, Smart and his coauthor believe that such ties can effectively solve agency problem and make workers feel obligated to stay with the factory during slow periods (Smart and Smart 1993). Sargeson (1999) shares similar findings that workers employed on the basis of guanxi often feel an obligation to repay the generosity of their employer-patrons and are thus more likely to be tied to their jobs. This particularistic way of managing a labor force is even regarded as "the spirit of Chinese capitalism" (Redding 1990).

Rapid industrialization and urbanization create massive migration from rural to urban areas, cultivating the making of a new working class that often has rural origins. This transition in occupational status and social identity raises important implications for employer-employee social ties. Taking China as an example, most rural migrants seek support from their families, kinship networks, and those with the same native place. Among them, the poorer and more disadvantaged migrants resort to richer and 
more established community members to settle and find a job (Solinger 1999). Facing an unfamiliar and exclusive environment, these newly arrived urban residents often maintain traditional social networks. The institutional discrimination and exclusion in employment, housing, and social insurance provision also reinforce the migrants' dependency on primary social ties to secure information and opportunities (Li 1996; Ma and Xiang 1998).

Researchers pay special attention to native-place ties in the workplace and have made breakthroughs with relevant theories, such as relational hegemony (Guanxi Baquan) (Shen and Zhou 2007) and the reverse order in paying off workers (Ni Chaxugeju) (Cai and Jia 2009). These theories all point out that managers naturally use native-place ties to mobilize and control workers; without social ties, the employer-employee relationship turns to sheer economic exchange and has to rely on monetary incentives to bring about effort and commitment (Zhou 2007). Household-based microentrepreneurs are another typical case in which social ties play an essential role in labor control. Particularistic hiring and patriarchal leadership create an atmosphere that obscures exploitation, changes workers' perceptions about distributive justice and fair treatment, and transforms a formal contractual relation into a premodern, feudalist dependency with certain obligations and entitlements, eventually inducing commitment and compliance from employees (Chen 2011; Tong 2005).

However, there is the other side of the coin. Some researchers argue that hiring acquaintances can cause problems and conflicts. On the one hand, it generates trust and reduces misunderstanding, which makes it easier to construct employment relations based on asymmetrical reciprocity. On the other hand, extracontractual social ties pose challenges for employers regarding discipline and control. They provide an easy excuse for those who are acquainted with the employer to ask for special treatment, and if not satisfied, they could become less-obedient and less-committed troublemakers. Using kinship as an example, if a relative's productivity and performance is below standard, can the employer easily fire him/ her? Usually, they cannot because such action would have far-reaching consequences on one's social relationships with other kin. Hiring kin is both a benefit and a cost, and requires the employer to balance the interests of kinship obligations and business efficiency (Smart and Smart 1993). This is exactly the same case as in prereform Chinese state-owned factories, which are full of factions and cliques. These small informal groups are usually founded on the exchange of loyalty and mutual assistance between cadres and workers. One way of making the system work is to make sure that the "right person" gets the rewards, including promotions and transfers (Walder 1986).

In an interview, one general manager from a midscale garment manufacturer stated that he often tries to avoid using relatives and kin in management positions:

I rarely appoint kin to any important position. Unlike many other bosses, I see kin as more trouble. They often have their own opinions and mismatched capacity, different from what you expect. I hate the idea that before making any decisions I have to consult them and try to make them ally with the company's interest. If so, the company will surely suffer from low efficiency. For any organization, ... centralized power is necessary. If top leadership includes relatives and kin, centralization is a hard task and operation costs will be too high. (XCS-01-131201) 
An electronic-component producer raises a theory on how to build a team exclusively loyal to him. Apart from spiritual motivation, he also gives "his man" shares of stock as gifts. He believes that this can build a highly cohesive team based not only on the company's vision, but on profit sharing as well. "You cannot unite your team with only big words and vision. Now everyone is kind of realistic about what they can actually get from you. Of course, sheer economic interests are fragile ... the shared vision is fundamental. You must know that kinship alone gives no guarantee that the kin will share your vision more strongly than nonkin" (ZT-02-131,117).

Employees' remarks also lend support to the Janus face of social relations. On the one hand, the workers tend to be more obedient due to shared social ties with their employer, while on the other hand, they expect a certain reciprocity and particularistic treatment from such relations. One worker who received his job through his acquaintance with the manager makes this point quite clear:

He [the manager]) brought me to this job, for which I feel grateful. Sometimes he asks me to work overtime, I simply accept. Occasionally I do him this favor and he needs to pay me back. When his wife goes back to our village she usually brings some gifts for my kids. This is the way of doing things here. When there is a high season in the production he also order other workers to work overtime, but often in vain. You know, nowadays the youngsters on the production line do not care about money as the older generation does. They just come to enrich their experience. Even if you promise higher overtime wages it is not easy. The manager usually needs his own man, but if he overlooks the favors that we do for him then there is no point in carrying on this relation. (ZT-07-131118)

This reminds us of the empirical controversy in the role of guanxi. To understand different empirical findings, we need to take into consideration the two faces of social relations: the cultural face versus the instrumental face. Many researchers highlight social relations as culturally bound unconditional constraints for those tied to each other. They believe that social relations can easily turn formal controls and compliance between employers and employees into an informal implicit consensus in which employees regard their employers as part of "us" and thus comply with employers' orders. However, the reality is far more sophisticated. Employees naturally expect particularistic treatment from such social ties, either material or nonmaterial rewards. At the same time, the employer tends to distribute resources based on social ties in order to exchange them for commitment. Under some conditions, the cultural face will dominate, while in other contexts, the instrumental concerns prevail.

We now come to the first set of hypotheses that attempt to test whether native-place ties between employers and employees have an impact on employees' commitment. The next section discusses the contexts that can intensify or weaken the role of nativeplace ties.

H1.1: In the workplace, those who share native-place ties with their employer are usually more content with the employer's domination and thus have a higher level of organizational commitment compared to their co-workers.

H1.2: As the strength of these ties increases, the employees' commitment increases as well. 
H1.3: When these ties connect with higher-level management, the employees' commitment increases.

\section{What moderates the effect of social ties?}

We have already highlighted the instrumental face of guanxi. We argue that when social ties benefit employees in one way or another, they are more likely to embrace such asymmetric relations and more committed to the employer as a return for special treatment. Since socially tied individuals seldom obey unconditionally and usually deliberate on the implicit rights and obligations inherent to guanxi and behave accordingly, we thus need to discuss a series of truly important issues: Under what conditions does guanxi become more (or less) important? To what extent does the context make a difference to an individual's deliberation? In other words, what moderates the effect of social ties?

Let us make the first important proposition as a foundation for further discussion: The instrumental utility of social ties can be (partially) substituted. To illustrate this proposition further, socially tied individuals usually have more or less instrumental concerns. They expect to benefit somehow from the relations they are in. We argue that the benefit they get from social ties can be partially substituted.

We can now move on to the second proposition, which deals with the conditions of social ties. We argue that when employees can secure equivalent benefit from an alternative opportunity structure, they are less reliant on their relations with the employer, and the effect of social ties is therefore reduced. In contrast, when employees lack alternatives and have to rely solely on such social ties for resources, the effect of social ties is reinforced.

In an organization, employees usually mobilize their relations with their employer to secure valuable resources and better life chances. Apart from that, what else can workers do? Quite a few studies point out the vital role of the internal labor market as contrasted to the external labor market. As institutional economists argue, in order to avoid information asymmetry, the pricing, allocation, and training of labor, once completed at external labor markets, is then "internalized" and governed by a set of administrative rules and procedures within the firm to reduce the cost of screening, supervision, and labor replacement (Burawoy 1979; Doeringer and Piore 1971). This is the definition and function of the internal labor market. The internal labor market has a direct effect on the employee's organizational commitment. Once in a regular schedule of internal promotion and promised job security, workers tend to ally their interests with the firm's interests, and any action that is noncompliant or disloyal would be presumably detrimental to both the company and him- or herself (Lazear and Oyer 2012; Yang et al. 2004). ${ }^{4}$ By raising the opportunity cost of leaving the company, the internal labor market also makes the employee more likely to stick with their employer in an instrumental way (Becker 1993).

The internal labor market can stimulate affection attachment on the one hand and induce interest concerns on the other hand. These two faces are quite similar to the nature of social relations. Thus, we argue that the internal labor market can at least partially substitute for the instrumental role of social relations for two reasons:

First, the internal labor market may effectively reduce uncertainty for employees. As mentioned before, the original idea of the internal labor market is to handle agency problems, information asymmetry, and pervasive opportunism in the organization. Pursuing individualistic models cannot provide a logical explanation (Baker and Holmstrom 1995). The employers may acquire adequate knowledge about the employees' capacity and skills 
and make timely assessments of whether s/he matches the requirements of the position. By designing a set of career ladders for employees, the employer may reach an "implicit contract" of job security and wage insurance with their subordinates. ${ }^{5}$ Thus, the employees may get direction and signals, and provide commitment and effort in return (Crompton and Jones 1984). In a well-functioning internal labor market, the employer and employees are in a long-term exchange that reduces opportunism on both sides.

In the interviews, most employers emphasized that institutionalized promotion practices are crucial for stabilizing and motivating their labor force, both in the short term and the long run. A general manager from a private stone-processing plant indicated that promotion was the most effective way to make his men feel "fully motivated." Even if a worker has not yet been promoted to a formal managerial position, s/he would still be quite content if the employer treated him/her as the backbone of the team. "When the prospects are good they are naturally very happy. They are not that shortsighted or concerned about short-term personal gains or losses. In a company that develops rapidly, they look to the future. If the company does not move forward in its business, it will surely be difficult to maintain your men. As long as you give them a chance of moving upward they will definitely stay" (NS-01-131025).

Another manager from a metal-processing factory shared this opinion. She told me that almost all the managerial or technical staff were promoted internally rather than recruited from other companies: "They are more likely to take root, grow, and blossom in this way. If you directly recruit some technician from outside, he usually will not treat your company as his home. Let me make an analogy. You cannot move a big tree, and it will simply die. But for a sapling, it is easy for it to take root anywhere and grow" (YT-02-140113). She also pointed out that promotions could change the employees' understanding and "mental account" of the labor contract: "Actually, a so-called 'manager' does not have any subordinates he can command, but when he gets this managerial title he feels satisfied. The title gives him more authority, more work autonomy, and a more-comprehensive workload, which has a huge impact on the employees' mentality and psychological wellbeing. He will simply believe that the boss has his eye on him. Those who are not promoted yet will also feel their future looks promising" (YT-02-140113).

Second, the internal labor market often adopts an elaborate hierarchical system and selection criteria, which may institutionalize and structure informal social relations. Usually, we see a full set of human resource practices in a well-developed internal labor market. These practices may function according to different logics, sometimes meritocracy, sometimes loyalty-based, but compared to the "black box" of social relations, the internal labor market is often quite clear-cut in its criteria. We may say that resource allocation dominated by guanxi often follows some unwritten rules that are obscure and vague (Burawoy 1979; Edwards 1979) and present a face of "industrial feudalism" (Doeringer and Piore 1971). In contrast, the rules and regulations of the internal labor market are much more clear.

The question of how formal and informal institutions interact with each other has been discussed for decades (DiMaggio and Powell 1991; Nee 1998). Many argue that informal institutions are more like tacit knowledge recognized by everyone in the organization and are thus often cheaper to sanction and control by using informal rules. In this case, the informal rules can easily weaken, replace, or resist the adoption of formal regulations (Peng 2004; Guo et al. 2012). However, researchers often neglect 
the other side to this issue. When formal regulations are clear and easy to implement, they can also significantly reduce the effect of informal rules and sometimes even be able to integrate informal elements into formal settings and accomplish "structuration" of informal rules' effect (Knight 1992). This is exactly the case here. As a set of formal institutions, the internal labor market may well reduce the effect of employer-employee social ties and even replace the latter. As the internal labor market becomes more open to employees, the effect of social ties is moderated accordingly.

In an interview, one shop-floor manager raised a sharp point that perfectly reflected this mechanism: "Our boss always tells us when business is bad workers hang around, doing nothing and making no money; then they become troublemakers. They form small groups and fight ferociously with others. If business goes well, everybody gets a chance to live better, and there's no point in fighting" (YT-04-140113). This respondent was distantly related to the vice-general manager and recruited for that reason. $\mathrm{He}$ admitted that in the early years when the situation was difficult, he had little to do. When workers from different shop floors fought over trivial things, he naturally asked his distant relative to help: "You really need to have your own men, your own team. That's important. But in recent years the company has been steadily growing and business is getting better. You don't feel that way at all. After all, everyone comes here to seek a better life, and that's kind of a shared vision" (YT-04-140113).

We now come to the second hypothesis, to test the moderating role of the internal labor market on the effect of native-place ties between employers and employees:

$\mathrm{H} 2$ : Other things being equal, the openness of the internal labor market will moderate the effect of native-place ties. When the internal labor market becomes more open and provides more opportunity for employees, the effect of native-place ties on employees' organizational commitment will be reduced. In contrast, when the internal labor market becomes more closed, the effect of native-place ties will be augmented.

\section{Data, measurement, and model specifications}

Data used in this paper were collected in the Yangtze Delta region from two waves of a nested survey. These two surveys were conducted in 2011-2012 and 2012-2013 by the Institute of Sociology, Shanghai Academy of Social Sciences, and both contained enterprise-level and individual-level information. ${ }^{6}$ Due to the lack of firm information, most studies of employees' behavior and attitude only use individual-level data. Departing from those works, this study focuses on the firm-level opportunity structure and how it moderates the effect of employees' social relations. Enterprise-level data is thus a prerequisite.

The dependent variable here is organizational commitment. To measure this concept, we integrated the classical scale of Meyer and his colleagues (Meyer et al. 1993), and an innovative version proposed by Chinese organizational psychologists (Sun and Jiang 2009). It contains three key elements. The first is a feeling of belonging and identity, which means that employees feel a psychological dependency on the organization. In the Chinese context, employees usually regard their organization as the "family." Second, a consensus exists between the individual and organization, which implies employees' recognition of the organization's target, vision, and value system and whether s/he would ally with the organization's interests in decision-making. The third element is the 
attraction of the organization, meaning to what extent the employee feels proud of being part of the organization when assessing his/her social status and reputation.

In this survey, respondents were asked about their feelings toward the organization. We used the organizational commitment scale, comprised of seven items that measure the above three elements. Responses were made on a four-point scale (1=strongly disagree and $4=$ strongly agree) and were added to yield composite commitment scores. ${ }^{7}$ Finally, we produced a continuous variable measuring organizational commitment ranging from -14 to 14 , averaging 2.47 , with a standard error of 3.60. Table 1 shows the average score of each item.

The independent variable is employer-employee native-place ties in the workplace, specifically between the respondent and his/her boss, mid-level manager, or lower-level supervisor. We used three measurements in the analysis: (1) whether the native-place tie occurs between the worker and the owner of the factory, and how close it is; (2) whether the native-place tie occurs between the worker and the mid-level manager, and how close the closest tie is if there are many; and (3) whether the native-place tie occurs between the worker and the lower-level supervisor, and the how close the closest tie is if there are many.

Among the respondents, $15.37 \%$ revealed that they shared place of origin with the owner of the factory, $23.47 \%$ with the mid-level manager, and $31.99 \%$ with the lower-level supervisor. To further analyze the strength of such social ties, we made cross-tabulations and constructed a new variable with three values: close native-place tie, not-so-close native-place tie, no native-place tie. The overall distribution shows that it is easier to have a lower-level close native tie than a higher-level one. For instance, only 3.64\% claimed that they had close native-place ties with the factory owner, $7.65 \%$ claimed to be close with mid-level managers, and for lower-level supervisors the percentage increased to $13.65 \%$.

The moderator variable is the openness of the firm's internal labor market. We operationalized it as how many employees received a promotion annually in this organization. The survey did not collect this information at the firm level; thus, we aggregated individual-level information into group-level data. The aggregated variable is based on two items. The first item reflects the perceived probability of getting a promotion in upcoming years, with responses ranging from "definitely will be promoted" to "almost no chance." We recoded these responses to a dichotomous variable, with "almost no chance" recoded to 0 and the others to 1 . The second item reflects the promotion experiences of respondents in this

Table 1 Organizational commitment: average score for each item

\begin{tabular}{|c|c|c|}
\hline Dimensions & Items & $\begin{array}{l}\text { Average } \\
\text { score }\end{array}$ \\
\hline \multirow[t]{2}{*}{ Feeling of belonging and identity } & 1. I feel like "part of the family" at my organization. & .74 \\
\hline & $\begin{array}{l}\text { 2. I feel that the boss and managers truly care about } \\
\text { our well-being. }\end{array}$ & .46 \\
\hline \multirow[t]{3}{*}{$\begin{array}{l}\text { Consensus between individual and } \\
\text { organization }\end{array}$} & $\begin{array}{l}\text { 3. I often feel my interests do not ally with the firm's interests. } \\
\text { (Adverse item) }\end{array}$ & -.32 \\
\hline & $\begin{array}{l}\text { 4. All in all, I really feel as if this organization's problems are } \\
\text { my own. }\end{array}$ & .53 \\
\hline & $\begin{array}{l}\text { 5. I feel that my value system differs from what the firm tries } \\
\text { to nurture. (Adverse item) }\end{array}$ & -.42 \\
\hline \multirow[t]{2}{*}{ Attraction of organization } & 6. I am proud to be in this organization. & .64 \\
\hline & $\begin{array}{l}\text { 7. I would feel proud if the products we produce could be } \\
\text { sold to other countries. }\end{array}$ & .84 \\
\hline
\end{tabular}


organization by asking, "Have you been promoted in this organization, such as group leader, shop-floor supervisor, union committee member etc.?" We constructed another dichotomous variable, with "yes" recoded to 1 and "no" or "can't remember" to 0 . We then used these two dichotomous variables to construct a new variable, "the chance of getting a promotion." If either dichotomous variable gets a value of 1 then the chance of getting a promotion equals 1 and otherwise equals 0 . We proceeded to calculate the percentage of "1"s in each organization, implying the percentage of employees who already received a promotion or expected to be promoted. This measures the characteristics of the internal labor market: the higher the percentage, the more open opportunity structure the firm's internal labor market shows to its employees. In the total 282 firms that we surveyed, the highest percentage of getting or expecting a promotion was $100 \%$, implying that all the respondents in that firm had been or expected to be promoted in the near future. However, the lowest percentage was $4.3 \%$, a sharp contrast.

To rule out other confounding causes, we also controlled a set of individual- and group-level variables. Individual-level controls were gender, years of schooling, residential registration status (hukou), cohort, work experience, occupation, hourly wage (log), labor contract, social insurance (including pension, medical care, and work injury insurance), experience of being abused in the workplace, union membership, work autonomy, and democratic participation in the organization. Group-level controls were city, industry, ownership, scale, labor/capital intensive, human capital stock, and labor rights protection institutions (including trade union, party branch, or employees' representative congress). ${ }^{8}$ Table 2 presents the basic distribution of the above variables.

We obtained our results using a hierarchical linear model (HLM) since multilevel variables are included in the analysis. First, we needed to separate the total variability in the dependent variable, organizational commitment, using a null model. Table 3 presents the results of the null model. To be consistent with the following models, here, we omitted three samples that are missing in the income variable. The analytical sample totals 5046. We see the mean value of all respondents' commitment is 2.473 , denoting the intercept of the null model. If we separate the variability into two levels, variability between the organizations is 3.64511 and 8.94761 within the organizations. Chi-square equals 1300.74 , and under the degree of freedom, $p$ value approximates 0 , which means the variability between the organizations is statistically significant. We further calculated the variance component and found that firms do have an impact on employees' organizational commitment. This impact amounts to $28.95 \%$ of the total variability of commitment. In other words, intraclass correlation (ICC) is high enough that it cannot be ignored.

We then proceeded to examine the two sets of hypothesis. Here, there are several mechanisms. The first is the direct effect of employer-employee native-place ties on organizational commitment; second, the direct effect of the internal labor market on employees' organizational commitment; and third, how the internal labor market moderates the effect of native-place ties. We estimated the following model of three equations for the effects of native-place ties and the internal labor market:

Level 1 model:

$$
Y_{1}=\beta_{0}+\beta_{1} \times T_{i}+\beta_{2} \times Z_{i}+r
$$

Level 2 model: 
Table 2 Descriptive statistics of controls

\begin{tabular}{|c|c|c|c|c|c|}
\hline Individual-level & Freq. & Percentage & Group-level & Freq. & Percentage \\
\hline Gender & & & City & & \\
\hline Male & 3021 & 59.83 & Shanghai & 40 & 14.18 \\
\hline Female & 2028 & 40.17 & Nanjing & 40 & 14.18 \\
\hline Hukou status & & & Nantong & 40 & 14.18 \\
\hline Local urban & 970 & 19.21 & Changzhou & 40 & 14.18 \\
\hline Local rural & 846 & 16.76 & Hangzhou & 41 & 14.54 \\
\hline Nonlocal urban & 765 & 15.15 & Ningbo & 40 & 14.18 \\
\hline Nonlocal rural & 2468 & 48.88 & Wenzhou & 41 & 14.54 \\
\hline Cohort & & & Ownership & & \\
\hline Before 1980 & 1802 & 35.69 & State-owned & 21 & 7.45 \\
\hline 1980-1986 & 1378 & 27.29 & Private & 170 & 60.28 \\
\hline After 1986 & 1869 & 37.02 & Foreign & 20 & 7.09 \\
\hline Occupational class & & & Joint & 71 & 25.18 \\
\hline Managerial/technical & 345 & 6.83 & Industry & & \\
\hline Routine nonmanual & 515 & 10.20 & Electronics & 45 & 15.96 \\
\hline $\begin{array}{l}\text { Skilled worker/shop-floor } \\
\text { supervisor }\end{array}$ & 1592 & 31.53 & Garment & 66 & 23.40 \\
\hline Unskilled worker & 2597 & 51.44 & Mechanics & 92 & 32.62 \\
\hline Labor contract & & & Automobile assembly & 28 & 9.93 \\
\hline Yes & 3278 & 64.92 & Chemical engineering & 51 & 18.09 \\
\hline No & 1771 & 35.08 & Labor/capital intensive & & \\
\hline Social insurance & & & Labor intensive & 140 & 49.65 \\
\hline Yes & 2883 & 57.10 & Capital intensive & 142 & 50.35 \\
\hline No & 2166 & 42.90 & $\begin{array}{l}\text { Labor rights protection } \\
\text { institution }\end{array}$ & & \\
\hline Workplace abuse & & & Yes & 105 & 37.23 \\
\hline Yes & 731 & 14.48 & No & 177 & 62.77 \\
\hline No & 4318 & 85.52 & Continuous variable & Mean & Sd. \\
\hline Union membership & & & Years of schooling & 10.66 & 2.47 \\
\hline Yes & 929 & 18.40 & Working experiences & 7.84 & 6.91 \\
\hline No & 4120 & 81.60 & Work autonomy & 4.58 & 1.69 \\
\hline $\begin{array}{l}\text { Democratic participation } \\
\text { in the workplace }\end{array}$ & & & Hourly wage & 13.37 & 5.41 \\
\hline Yes & 1277 & 25.29 & Scale of organization & 267.91 & 569.08 \\
\hline No & 3772 & 74.71 & Human capital stock & 21.17 & 15.67 \\
\hline
\end{tabular}

Table 3 Organizational commitment: results of the null model

\begin{tabular}{lllllll}
\hline Fixed effect & Coef. & S.E. & & & & \\
Organizational commitment & 2.473 & .122 & & & \\
Random effect & Variance component & Percentage of total variance & df & $x^{2}$ & $p$ value \\
Level 2 effect (between cluster) & 3.64511 & 28.95 & 281 & 1300.74 & 0.000 \\
Level 1 effect (within cluster) & 8.94761 & & 71.05 & & & \\
\hline
\end{tabular}




$$
\begin{aligned}
& \beta_{0}=\gamma_{00}+\gamma_{01} \times I L M+\gamma_{02} \times Z_{g}+\mu_{00} \\
& \beta_{1}=\gamma_{10}+\gamma_{11} \times I L M+\mu_{10}
\end{aligned}
$$

where $T_{i}$ is a categorical variable for native-place ties (close tie $=2$, not-so-close tie $=1$, no tie=0), ILM stands for the openness of the internal labor market, $Z_{i}$ contains individual-level controls, $Z_{g}$ contains group-level controls, $\beta$ stands for the parameters to be estimated, $r$ stands for error terms at the individual level, and $\mu$ stands for error terms at the group level. Equation (1.1) estimates the direct effect of native-place ties on commitment after controlling individual-level characteristics. Equation (2.1) is the intercept model, estimating the direct effect of firm-level controls and the internal labor market on employees' organizational commitment. Equation (2.2) is the slope model, estimating the moderating effect of the internal labor market and to what extent $\beta_{1}$ varies with the openness of the firm's internal labor market.

\section{Research findings}

Table 4 presents the direct effect of employer-employee native-place ties on organizational commitment. ${ }^{9}$ The first column reports the results of model 1, which contains the baseline controls. In models 2 to 4 , we respectively added three measurements of the independent variable and their random parts: the native-place tie between employees and their boss, midlevel, manager and lower-level supervisor. Model 5 reports the results of the full model, which includes all three measurements of the independent variable, and presents the net effect of each type.

First, we find that native-place ties do not guarantee a higher level of organizational commitment unless these ties are relatively strong. To be specific, those who have close ties with their superintendents usually show a higher level of loyalty compared to those who do not have such connections at all. However, those who have such connections but not as close reveal an even-lower level of commitment compared to those who lack such connections.

Models 2 to 4 demonstrate that for each type of native-place ties, close ties have a positive effect on organizational commitment while the effect of not-so-close ties is negative. Specifically, close native-place ties increase the commitment of those who share place of origin with their primary boss by 0.53 units, compared with those who have no such connections, while not-so-close ties decrease commitment by 0.51 units $(p<.05)$, compared to the reference group. Model 3 reveals a similar pattern. Those who have close native-place ties with their mid-level manager show higher commitment $(p<.1)$, while not-so-close ties decrease commitment by 0.21 units. Model 4 presents similar results on the coefficients, though not statistically significant. We can thus summarize two points. First, Hypothesis 1.1 is partially supported, which means the closeness or strength of native-place ties is vital to enhancing commitment and not-so-close ties make the commitment even more fragile. Second, Hypothesis 1.2 gets support since close ties indeed nurture a higher level of commitment.

These findings interestingly reflect the Janus face of social relations discussed before. As we see from Table 4, the strength of native-place ties has a different effect on employees' commitment: close ties enhance the commitment, while not-so-close ties weaken the commitment. The Janus-face argument states that social relations between employers and employees may culturally command the employees' compliance but at the same time practically elicits a higher expectation of special treatment from the employers. To go one 
Table 4 Native-place ties and organizational commitment: a direct effect

\begin{tabular}{|c|c|c|c|c|c|}
\hline & $\begin{array}{l}\text { Model } 1 \\
\text { Controls }\end{array}$ & $\begin{array}{l}\text { Model } 2 \\
\text { With owner }\end{array}$ & $\begin{array}{l}\text { Model } 3 \\
\text { With mid-level } \\
\text { manager }\end{array}$ & $\begin{array}{l}\text { Model } 4 \\
\text { With lower-level } \\
\text { supervisor }\end{array}$ & $\begin{array}{l}\text { Model } 5 \\
\text { Full model }\end{array}$ \\
\hline Fixed effect & Coef. & Coef. & Coef. & Coef. & Coef. \\
\hline \multicolumn{6}{|l|}{ Native-place tie } \\
\hline \multicolumn{6}{|c|}{ With owner (no such tie as ref.) } \\
\hline Not-so-close & & $-.503^{* *}$ & & & $-.520^{* * *}$ \\
\hline Close & & .529 & & & .129 \\
\hline
\end{tabular}

With mid-level manager (no such tie as ref.)

Not-so-close

With lower-level supervisor (no such tie as ref.)

$$
\text { Not-so-close }
$$

Close

Controls (individual level)

$$
\begin{aligned}
& \text { Gender (male }=1 \text { ) } \\
& \text { Years of schooling }
\end{aligned}
$$

Hukou (local urban as ref.)

Local rural
Nonlocal urban
Nonlocal rural
Cohort (before 1980 as ref.)

$$
\begin{aligned}
& \text { 1980-1986 } \\
& \text { After } 1986
\end{aligned}
$$

Work experience

Occupational class (manager/technical as ref.)

Routine nonmanual
Skilled worker/shop floor
Unskilled worker

Hourly wage (log)

Labor contract (yes $=1$ )

Social insurance (yes $=1$ )

Workplace abuse (yes $=1$ )

Union membership (yes = 1)

Work autonomy

Democratic participation

Controls (group)

City

Industry

Ownership

(state-owned as ref.)

$\begin{array}{llllll}\text { Private } & -.652 & -.650 & -.738 & -.654 & -.638 \\ \text { Foreign } & -1.237^{* *} & -1.159^{*} & -1.238^{* *} & -1.198^{* *} & -1.221^{* *} \\ \text { Joint } & -.927^{*} & -.899^{*} & -.987^{* *} & -1.006^{* *} & -.906^{*}\end{array}$

$\begin{array}{ll}-.211 & .001 \\ .440^{*} & .401^{* *}\end{array}$

$\begin{array}{ll}-.168 & -.061 \\ .104 & .018\end{array}$

$\begin{array}{lllll}-.333^{* * *} & -.357^{* * *} & -.332^{* * *} & -.321^{* * *} & -.340^{* * *} \\ .052^{* *} & .057^{* *} & .052^{* *} & .051^{* *} & .054^{* *} \\ & & & & \\ -.175 & -.136 & -.129 & -.163 & -.145 \\ -.409^{* *} & -.435^{* *} & -.410^{* *} & -.428^{* *} & -.457^{* *} \\ -.331^{* *} & -.373^{* *} & -.329^{* *} & -.349^{* *} & -.384^{* *} \\ & & & & \\ -.205 & -.212 & -.215 & -.231^{*} & -.207 \\ -.296^{* *} & -.309^{* *} & -.295^{* *} & -.313^{* *} & -.295^{* *} \\ -.017^{*} & -.019^{* *} & -.019^{* *} & -.019^{* *} & -.169^{*}\end{array}$

$\begin{array}{lllll}-.214 & -.182 & -.163 & -.185 & -.210\end{array}$

$\begin{array}{lllll}-.382^{*} & -.354^{*} & -.332^{*} & -.366^{*} & -.367^{*}\end{array}$

$-.473^{* *}-.419^{* *} \quad-.395^{* *} \quad-.435^{* *} \quad-.439^{* *}$

$.638^{* * *} \quad .617^{* * *} \quad .600^{* * *} \quad .612^{* * *} \quad .593^{* * *}$

$\begin{array}{lllll}.177 & .191 & .187 & .209^{*} & .188\end{array}$

$\begin{array}{lllll}-.036 & -.008 & -.010 & -.028 & -.029\end{array}$

$\begin{array}{lllll}-.234^{*} & -.247^{*} & -.232^{*} & -.223^{*} & -.240^{*}\end{array}$

$\begin{array}{llll}.276^{*} & .313^{* *} & .280^{*} & .289^{*}\end{array}$

$\begin{array}{lllll}-.059^{*} & -.048 & -.052^{*} & -.059^{*} & -.047\end{array}$

$.301^{* * *} \quad .280^{* *} \quad .278^{* *} \quad .294^{* *} \quad .266^{* *}$

$\begin{array}{lllll}+ & + & + & + & +\end{array}$

$\begin{array}{llllll}+ & + & + & + & + \\ - & - & - & - & -\end{array}$


Table 4 Native-place ties and organizational commitment: a direct effect (Continued)

\begin{tabular}{|c|c|c|c|c|c|}
\hline & $\begin{array}{l}\text { Model } 1 \\
\text { Controls }\end{array}$ & $\begin{array}{l}\text { Model } 2 \\
\text { With owner }\end{array}$ & $\begin{array}{l}\text { Model } 3 \\
\text { With mid-level } \\
\text { manager }\end{array}$ & $\begin{array}{l}\text { Model } 4 \\
\text { With lower-level } \\
\text { supervisor }\end{array}$ & $\begin{array}{l}\text { Model } 5 \\
\text { Full model }\end{array}$ \\
\hline Fixed effect & Coef. & Coef. & Coef. & Coef. & Coef. \\
\hline Scale of organization (log) & -.009 & -.001 & .023 & -.017 & .013 \\
\hline Labor intensive & .165 & .154 & .146 & .188 & .202 \\
\hline Human capital stock & -.006 & -.006 & -.006 & -.004 & -.006 \\
\hline Rights protection institutions & .006 & .011 & .059 & .195 & .001 \\
\hline Intercept & $3.141^{* * *}$ & $3.177^{* * *}$ & $3.011^{* * *}$ & $3.120^{* * *}$ & $3.188^{* * *}$ \\
\hline Random effect & Sd. & Sd. & $\mathrm{Sd}$ & Sd. & Sd. \\
\hline Level 2 effect & 1.758 & 1.763 & 1.828 & 1.812 & 1.746 \\
\hline Level 1 effect & 2.962 & 2.929 & 2.915 & 2.929 & 2.957 \\
\hline Deviance & $25,823.8$ & $25,791.3$ & $25,782.1$ & $25,803.4$ & $25,804.9$ \\
\hline Level 2 observation & 282 & 282 & 282 & 282 & 282 \\
\hline Level 1 observation & 5046 & 5046 & 5046 & 5046 & 5046 \\
\hline
\end{tabular}

step further, the cultural and instrumental faces of social relations may correspond to the strong tie and weak tie respectively. A strong tie usually elicits tight cultural constraints and in return brings more interest to those who obey. On the contrary, a weak tie is usually not strong enough to culturally obligate the employer and employees to cater to each other's needs and sometimes only produces instrumental desires while being devoid of cultural constraints.

Second, other things being equal, as the level of guanxi gets higher, it has a greater effect in eliciting commitment. If the employee has the same place of origin as his/her boss, such a connection enhances the employee's organizational commitment by 0.53 units. In comparison, a close native-place tie with a mid-level manager enhances 0.44 units of commitment, while a close tie with a lower-level supervisor only enhances it by 0.1 units. Scholars still hold different opinions about the effect of the last type of native-place ties. Some argue that lower-level supervisors are part of the hierarchical management system, the grassroots controls at the shop-floor level, and thus, it is fair to say that they exercise domination on ordinary laborers. Following this logic, the native-place ties between workers and lower-level supervisors will contribute to building the employee's commitment. However, Table 4 does not seem to indicate adequate support to this standpoint: the effect of such ties is so weak, if not nonexistent, that it is more like a horizontal connection and solidarity among ordinary workers rather than a vertical tie between workers and their managers.

Considering that each respondent may have more than one type of native-place ties, we present model 5 as a full model that contains all three types of native-place ties so that we can assess the net effect of each type and compare the results with previous models. Model 5 reveals that a higher level of native-place ties has a larger net effect on organizational commitment. The effect of the lowest level of native-place ties is overshadowed by the effect of other types of ties, which means that if the employee has more than one type of nativeplace ties, the effect of lower-level ties would be more "invisible." This finding lends support to our argument that the level of social ties does matter. Therefore, Hypothesis 1.3 also gets partial support, but the relationship between the levels of social ties and commitment is not 
linear. Native-place ties with lower-level supervisors do not guarantee the employees' attachment to the organization; at the same time, the connection with the factory owner is no more useful than a connection with a mid-level manager in that regard. Referring to what was discussed in previous sections, this nonlinear relation perfectly reflects the complexity of guanxi in general. Sometimes the cultural constraints of guanxi may dominate while sometimes it only shows sheer instrumental concerns; what is worse, we hardly know the reason why this occurs. As the level of guanxi gets higher, subordinates may identify more with their superintendents and accept whatever they demand; at the same time, the subordinates may also have greater expectations and ask for more reciprocity from their superintendents. These tendencies tremendously influence the effect of social ties.

We now proceed to analyzing the effect of the internal labor market (ILM). Table 5 presents the main findings in this regard. Setting models 2 to 4 as the baseline, models 2.1 to 4.1 further add a new variable, the openness of ILM. We find that when the organization has a more open ILM, employees usually have a higher level of commitment. The direct effect of ILM on commitment is quite significant: as the openness of ILM increases by 1 unit, organizational commitment correspondingly improves by 2.3 units. In addition, ILM has a strong net effect on enhancing commitment. After adding ILM, the effects of the independent variable and most controls are not considerably reduced except for the effect of ownership. To some extent, the openness of ILM does reduce previous differences between state-owned enterprises and the non-state sector in employees' organizational commitment. That is, state-owned enterprises enjoy a higher level of employee's commitment, partly due to the fact that they provide more opportunity for promotion.

Now let us move to the moderating effect of ILM, as presented in models 2.2 to 4.2. We further add coefficient models (as indicated in Eq. 2.2) to the previous models 2.1 to 4.1. The coefficient models contain ILM as the independent variable and the direct effect of native-place ties $\left(\beta_{1}\right)$ as the dependent variable in order to analyze how ILM moderates the effect of social ties.

Table 5 reveals the interesting finding that as the ILM becomes more open, the effect of social ties is considerably reduced. Such reduction of effect is significant in all three types. Taking model 2.2 as an illustration, since the openness of ILM is a positive number ranging from 0 to 1 , the sign of $\gamma_{11} \times I L M$ is up to the sign of $\gamma_{11}$. In model 2.2, $\gamma_{11}$ has values of -3.952 and -2.485 ; thus, $\gamma_{11} \times I L M$ has a negative value. This indicates that as the openness of ILM increases, the $\beta_{1}$ decreases and ILM reduces the effect of the independent variable.

If native-place ties between employees and their bosses are strong and close, as the ILM increases its openness by 1 unit, the effect of strong ties on commitment is reduced by 3.952 units $(p<.01)$; if such ties are not so close, then as the ILM becomes more open by 1 unit, the effect of weak ties is reduced by 2.485 units $(p<.01)$. Similar results are presented in models 3.2 and 4.2. For close guanxi between employees and mid-level managers, a 1-unit increase in ILM openness reduces the effect of guanxi by 1.931 units $(p<.05)$; for not-so-close ties, the reduction is 0.883 units. For close guanxi with lower-level supervisors, a 1-unit increase in ILM mitigates the effect by 1.547 units $(p<.05)$ and for not-so-close guanxi, the reduction is 0.260 units. Hypotheses 2.1 and 2.2 both get strong support.

Finally, after adding coefficient models, we still witness a significant direct effect of ILM on organizational commitment. Models 2.2 to 4.2 show that a 1-unit increase in the 


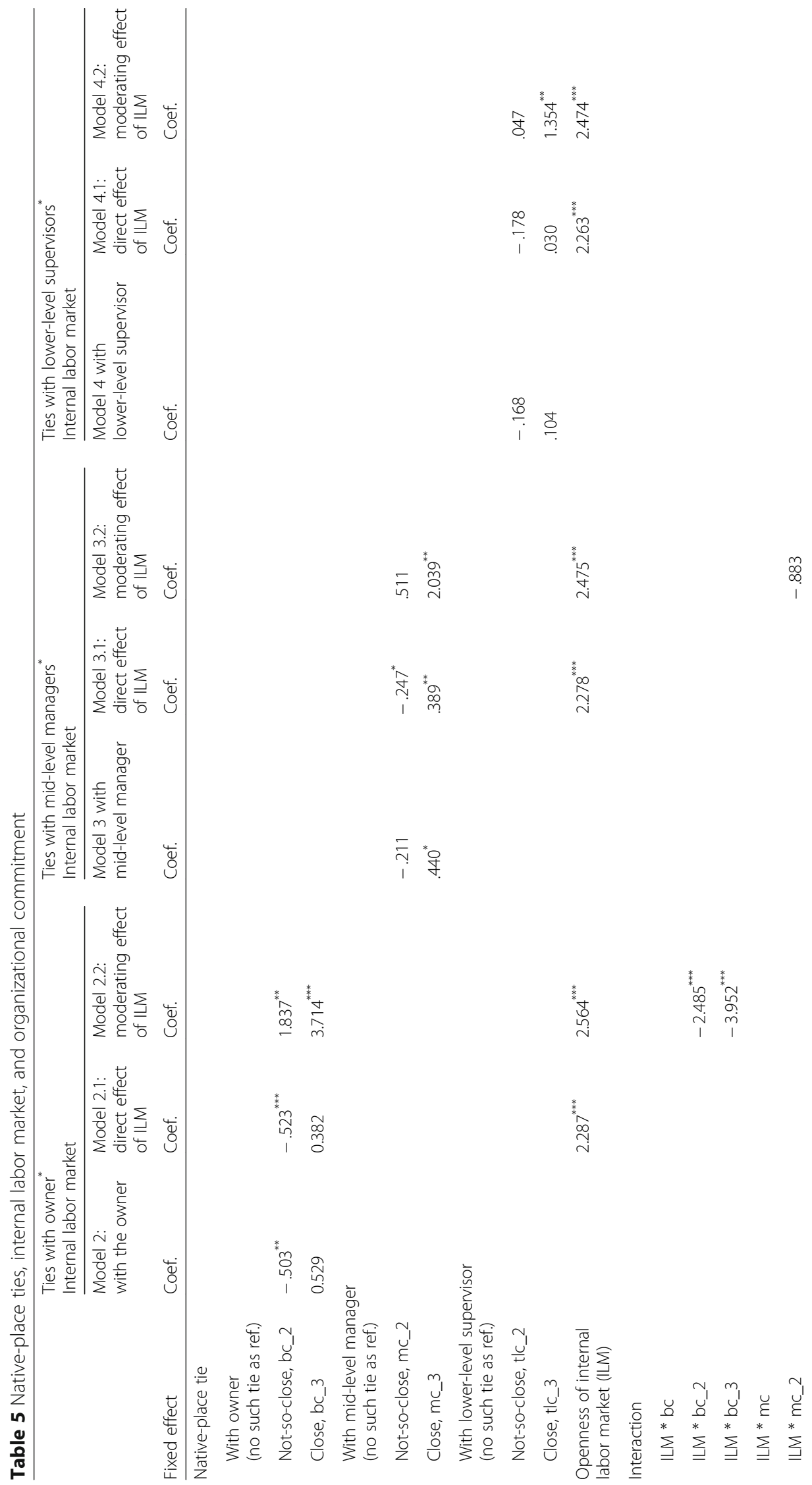




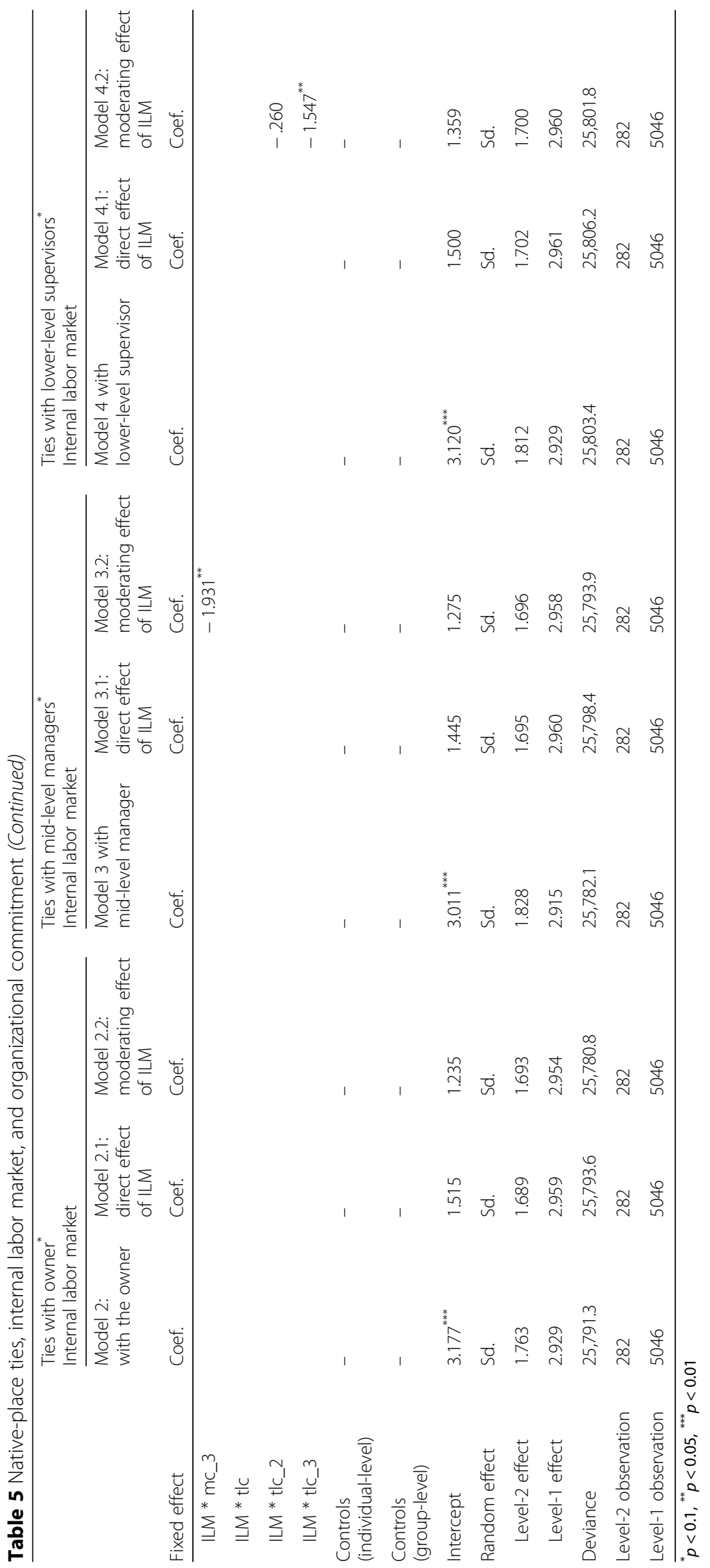


openness of ILM would respectively enhance an employee's organizational commitment by $2.287,2.278$, and 2.263 units.

\section{Conclusions}

Commitment and shirking in employment relations have long received scholarly attention. At an earlier stage, economics emphasized the role of "efficiency wage" (Shapiro and Stiglitz 1984), but later, economists made substantial theoretical revisions to add social and relational elements to their models (Akerlof and Yellen 1986), emphasizing that these elements, often extracontractual, make the contract-based labor exchange more or less reciprocal. Political scientists also point out the importance of nonmarket institutions for controlling the incentive to shirk or cheat in the labor market (Krieg et al. 2013). From another perspective, legal experts argue that relying solely on laws and decrees will not elicit adequate commitment. All these standpoints urge researchers to broaden their horizons and study the roles of ubiquitous informal institutions and pervasive guanxi.

Seminal works in economic sociology argue that extracontractual social relations between employers and employees have a profound impact on employees' behavior and attitude toward the organization, which is referred to as the social embeddedness of employment relations. However, most follow-up studies merely focus on the effect of social relations and discuss whether social embeddedness has an impact. Such replicative studies obviously lack the capacity of advancing our understanding and disappointingly impair the preciseness of this concept (Fu 2009; Liu 2015). Some scholars have noted the context of social embeddedness, arguing that social behavior and attitude are constrained by informal institutions, but such constraints are themselves subject to certain larger structures (Wang 2008). Researchers have attempted to create some formal analytical framework but have not yet applied the framework to test it empirically.

This study takes a slightly different approach. It does not use empirical data to test the size of the effect of social embeddedness but to address a theoretical question raised by the sociology of knowledge, "How does ideology work?" (DiMaggio and Powell 1991). We propose several statements to construct our theoretical framework:

The first statement argues that people comply with informal institutions partly due to the moral restrictions but more likely due to their instrumental concerns. This argument is not at all original. Social network researchers have already noted the multifaceted nature of guanxi as both emotional bonds and an instrumental toolkit. Lin (2001) argues for the relational basis for social exchange, the so-called "relational rationality" built on pervasive asymmetrical social exchanges. Both of the trading parties tend to sustain their mutual commitment, trust, and affection through instrumental ways. However, scholars also admit the lack of systematic inquiry into the empirical consequences and contexts of multifaceted social relations (Bian 2010).

This work does not stop with pointing out that social relations have two faces. Instead, we proceed to the second statement, that the instrumental concerns of complying with social relations can be (partially) substituted. When people can secure equivalent or more profits through alternatives, they are less constrained by social relations. Thus, the effect of guanxi will be reduced. In this way, we may be able to analyze the contexts and conditions of social relations in an indirect way.

In several articles, Bian and his coauthors analyze whether the effect of social networks on job seekers' entry-level wage varies across different sectors. They find that network 
effects are stronger in less-institutionalized sectors, which to some extent addresses the contexts of guanxi (Bian and Huang 2015; Bian and Zhang 2014). These results merit further investigation. For instance, what does the institutionalization of sectors really mean? What is the mechanism behind this moderation effect? After all, the sector is such a broad issue with so much internal variation, and it is probably not suitable as an ideal measurement of context.

Using qualitative data and existing literature, we constructed a theoretical framework and tested its empirical validity using a novel employer-employee nested dataset. We argue first that native-place ties can elicit organizational commitment so long as such ties are strong and constructed at the higher level. This also accounts for the instrumental characteristic of social relations in general. Second, if such instrumental concerns can somehow be taken care of through alternative ways, employees feel it is less necessary to secure their particularistic ties with the employers. Third, the internal labor market in an organization is an important alternative for employees. In a more open internal labor market, employees can get better life chances and opportunities for upward mobility; the effect of native-place ties on commitment is then reduced. In contrast, in a more closed internal labor market, employees have no alternative but to rely on their personal ties with employers, which enhances the effect of guanxi.

In regard to the problems and deficits of this paper, the limitations of the data prevented us from adopting a better conceptualization and operationalization of the internal labor market. In theory, the internal labor market is much more than just promotions; it includes pricing, allocation, and training of labor. In model specification, the aggregation of individual-level data also creates measurement errors. We therefore need more grouplevel information about career ladders and job allocation to make up for this issue.

Another problem is the lack of treatment for endogeneity between native-place ties and organizational commitment. Not all the employees share native-place connections with their employers. It is reasonable that some latent factors could create a situation in which some employees have better chances to be socially connected with their bosses, and the same factors elicit higher commitment from those employees. To solve this endogeneity problem, we need to find an effective instrumental variable that correlates with native-place ties but is uncorrelated with commitment in order to come to a more credible conclusion.

\section{Endnotes}

${ }^{1}$ The new working class in China has led to a huge number of migrant workers flowing from rural to urban areas, often employed in non-state sectors. This contrasts to the old working class that was made up of state-employed laborers who enjoyed permanent employment and social insurance, as was typically the case in the planned economy. See Chan and Pun 2009.

${ }^{2}$ The Hawthorne Experiments were conducted between 1924 and 1932 at the Western Electric Company, Hawthorne Works, in Chicago. During these experiments, a research team from Harvard Business School led by Elton Mayo discovered illuminating results about human relations in the workplace and their impact on productivity. These findings formed the basis for the school of human relations in the social sciences.

${ }^{3}$ We need to briefly state here that the institutionalization of labor contracts is far more complicated than with other types of contracts. According to what labor contracts prescribe, wage laborers trade "labor power" for money. Labor power differs from other 
traded things in that it is inseparable from those who sell labor and largely depends on the aspirations and willingness of those who own it. Although the labor contract may stipulate the quantity and quality of traded labor power, it is still practically difficult for employers or a third party to enforce the contract. In other words, it often lacks "exogenous claim enforcement" (Bowles and Gintis 1993, 166-67).

${ }^{4}$ Prof. Shu Keng has suggested careful reading of the seminal works by Edward Lazear and his colleagues. His suggestion is truly appreciated.

${ }^{5}$ The author thanks an anonymous reviewer for pointing out the links between "implicit contracts" and the internal labor market.

${ }^{6}$ Data collected by these two waves of surveys are cross-sectional rather than panel and include different enterprises. Seven cities were deliberately chosen as representing the industrial development level in this region: Shanghai, Nanjing, Nantong, Changzhou, Hangzhou, Ningbo, and Wenzhou. Five labor-intensive industries were targeted: electronics, garment, mechanics, automobile assembly, and chemical engineering. Enterprises were sampled according to the distribution of industry, ownership, and scale in each city. In total, 282 enterprises and 5049 employees were interviewed. Among the employees, production workers comprised more than $80 \%$. Due to space limitations, we do not present the distribution of samples here, but the results are available upon request.

${ }^{7}$ Before doing that, the author first calculated the Cronbach value of this measurement scale. According to a general rule, if the value is between 0.7 and 0.8 , it denotes an acceptable level of measurement consistency. If the value is above 0.8 then the level of consistency is fairly high and thus reliable. The result of the calculation is 0.84 , meaning that these seven items are internally consistent in the measurement.

${ }^{8}$ Information on measurement of controls is available upon request.

${ }^{9}$ Here, we adopted a random-coefficient model. After making lrtest, we rejected the hypothesis that random slope equals zero. We thus decided to add the random effect of the independent variable in model specifications.

Acknowledgements

The author thanks the helpful comments from Prof. Xin Liu in Fudan University.

Funding

This study was sponsored by the Shanghai Academy of Social Science, 2017-034, "Enterprise Trade Union, Skill Differentiation, and Employment Relation in China."

Availability of data and materials

Data and materials are available upon request.

Author's contributions

The author read and approved the final manuscript.

Competing interests

The author declares that she has no competing interests.

Received: 26 January 2018 Accepted: 3 April 2018

Published online: 18 April 2018

References

Akerlof, George A., and Janet L. Yellen. 1986. Efficiency wage models of the labor market. Cambridge: Cambridge University Press.

Aldrich, Howard E., and Roger Waldinger. 1990. Ethnicity and entrepreneurship. Annual Review of Sociology 16: 111-135.

Arrighi, Giovanni. 1970. Labour supplies in historical perspective: a study of the proletarianization of the African peasantry in Rhodesia. Journal of Development Studies 6 (3): 197-234.

Baker, George, and Bengt Holmstrom. 1995. Internal labor markets: too many theories, too few facts. American Economic Review 85 (2): 255-259. 
Baron, James N. 1988. The employment relation as a social relation. Journal of the Japanese and International Economies 2: 492-525.

Becker, Gary S. 1993. Human capital: A theoretical and empirical analysis with special reference to education. 3rd ed. New York: Columbia University Press.

Bian, Yanjie. 2002. Institutional holes and job mobility processes: Guanxi mechanisms in China's emergent labor markets. In Social connections in China, ed. T. Gold, D. Guthrie, and D. Wank, 117-135. Cambridge: Cambridge University Press.

Bian, Yanjie. 2010. Relational sociology and its disciplinary status. Journal of Xi'an Jiaotong University (Social Sciences) 30 (3): 1-6.

Bian, Yanjie, and Xianbi Huang. 2015. Beyond the strength of social ties: Job search networks and entry-level wage in urban China. American Behavioral Scientist 59 (8): 961-976.

Bian, Yanjie, and Lei Zhang. 2014. Corporate social capital in Chinese Guanxi culture. In Research in the sociology of organizations, ed. Daniel J. Brass et al., vol. 40, 421-443. Bingley: Emerald Group Publishing Limited.

Bowles, Samuel, and Herbert Gintis. 1993. The revenge of homo economicus: contested exchange and the revival of political economy. Journal of Economic Perspectives 7 (1): 83-102.

Burawoy, Michael. 1976. The functions and reproduction of migrant labor: comparative material from Southern Africa and the United States. American Journal of Sociology 81 (5): 1050-1087.

Burawoy, Michael. 1979. Manufacturing consent: changes in the labor process under monopoly capitalism. Chicago: University of Chicago Press.

Cai, He, and Wenjuan Jia. 2009. The reverse order in paying off workers by contractors in the Chinese construction industry: for whom is the market risk reduced by "Guanxi"? Society 5: 1-20.

Chan, Chris King-Chi, and Ngai Pun. 2009. The making of a new working class? A study of collective actions of migrant workers in South China. The China Quarterly 198: 287-303.

Chen, Qiuhong. 2011. Household as factory: an exploratory study of rural industrialization in North Town, Hebei Province. In Sociological master degree papers from three universities, ed. Yefu Zheng, Yuan Shen, and Suiming Pan, 1-54. Beijing: Chinese Youth Press.

Coase, Ronald H. 1937. The nature of the firm. Economica New Series 4 (16): 386-405.

Crompton, Rosemary, and Gareth Jones. 1984. White-collar proletariat: Deskilling and gender in clerical work. London: Macmillan Press.

Crozier, Michael. 2010. The bureaucratic phenomenon. London and New York: Routledge.

DiMaggio, Paul J., and Walter W. Powell. 1991. Introduction. In The new institutionalism in organizational analysis, ed. W. W. Powell and P.J. DiMaggio, 1-38. Chicago: University of Chicago Press.

Doeringer, Peter B., and Michael J. Piore. 1971. Internal labor markets and manpower analysis. Lexington: Heath Lexington Books.

Edwards, Richard C. 1979. Contested terrain: The transformation of the workplace in the twentieth century. New York: Basic Books.

Fu, Ping. 2009. Embeddedness: divergence and controversy. Sociological Studies 5: 141-164.

Goldthorpe, John, and Abigail McKnight. 2006. The economic basis of social class. In Mobility and inequality: frontiers of research from sociology and economics, ed. S.L. Morgan, D.B. Grusky, and G.S. Fields, 109-136. Stanford: Stanford University Press.

Granovetter, Mark. 1974. Getting a job: a study of contacts and careers. Cambridge: Harvard University Press.

Granovetter, Mark. 1992. The sociological and economic approaches to labor market analysis: a social structural view. In The sociology of economic life, ed. M. Granovetter and R. Swedberg, 233-264. Boulder: Westview Press Inc.

Guillen, Mauro F. 1994. Models of management: work, authority, and organization in a comparative perspective. Chicago: University of Chicago Press.

Guo, Yunnan, Yang Yao, and Jeremy Foltz. 2012. The formal and informal authority, the accountability and the smooth consumption: the data from the experience from China's Villages. Management World 1:67-78.

Hill, Stephen. 1981. Competition and control at work: the industrial sociology. Cambridge: MIT Press.

Katzenstein, Peter J. 1985. Corporatism and change. Ithaca: Cornell University Press,

Knight, Jack. 1992. Institutions and social conflict. Cambridge: Cambridge University Press.

Krieg, John M., Charles S. Wassell Jr., David W. Hedrick, and Steven E. Henson. 2013. Collective bargaining and faculty job satisfaction. Industrial Relations 52 (3): 619-644.

Lafaye, Claudette. 2000. Sociologie des Organisations (in Chinese), trans. An Yan. Beijing: Social Sciences Academic Press.

Lazear, Edward P., and Paul Oyer. 2012. Personnel economics. In The handbook of organizational economics, ed. R. Gibbons and J. Roberts, 479-519. Princeton: Princeton University Press.

Li, Peilin. 1996. Social network and social status of migrant workers. Sociological Studies 4: 42-52.

Lin, Nan. 2001. Guanxi: A conceptual analysis. In The Chinese triangle of mainland China, Taiwan, and Hong Kong: comparative institutional analysis, ed. A.Y. So, N. Lin, and D. Poston, 153-166. Westport: Greenwood Press.

Liu, Shiding. 2015. Different concepts, logical relations and expanding research about the term 'embeddedness'. In Chinese economic sociology research, ed. Shiding Liu, vol. 2, 1-17. Beijing: Social Sciences Academic Press.

Ma, Laurence J.C., and Biao Xiang. 1998. Native place, migration and the emergence of peasant enclaves in Beijing. China Quarterly 155: 546-581.

Mayo, Elton. 2003/1933. The human problems of an industrial civilization. London: Routledge.

Merton, Robert K. 1936. The unanticipated consequences of purposive social action. American Sociological Review 1 (6): 894-904

Meyer, John P., Natalie Allen, and Catherine A. Smith. 1993. Commitment to organizations and occupations: extension and test of a three-component conceptualization. Journal of Applied Psychology 78 (4): 538-551.

Miller, Gary J. 1992. Managerial dilemmas: The political economy of hierarchy. Cambridge: Cambridge University Press.

Mühlau, Peter, and Siegwart Lindenberg. 2003. Efficiency wages: signals or incentives? An empirical study of the relationship between wage and commitment. Journal of Management and Governance 7 (4): 385-400.

Nee, Victor. 1998. Norms and networks in economic and organizational performance. American Economic Review 88 (2): $85-89$ 
Peng, Yusheng. 2004. Kinship networks and entrepreneurs in China's transitional economy. American Journal of Sociology 109 (5): 1045-1074.

Perry, Elizabeth J. 1993. Shanghai on strike: The politics of Chinese labor. Stanford: Stanford University Press.

Portes, Alejandro. 2010. Economic sociology: A systematic inquiry. Princeton: Princeton University Press.

Redding, Gordon S. 1990. The spirit of Chinese capitalism. Berlin: Walter de Gruyter.

Sargeson, Sally. 1999. Reworking China's proletariat. New York: St. Martin's Press, Inc.

Selznick, Philip. 1949. TVA and grassroots. Berkeley: University of California Press.

Shapiro, Carl, and Joseph E. Stiglitz. 1984. Equilibrium unemployment as a worker discipline device. American Economic Review 74 (3): 433-444.

Shen, Yuan, and Xiao Zhou. 2007. 'Relational hegemony': A study of labor process of construction workers. In Market, class and society: critical inquiries on sociology of transition, ed. Y. Shen, 194-272. Beijing: Social Sciences Academic Press.

Shih, Kuo-heng. 1944. China enters the machine age: A study of labor in Chinese war industry (in Chinese). Beijing: The Commercial Press.

Smart, Josephine, and Alan Smart. 1993. Obligation and control: employment of kin in capitalist labour management in China. Critique of Anthropology 13 (1): 7-31.

Solinger, Dorothy. 1999. Contesting citizenship in urban China: peasant migrants, the state, and the logic of the market. Berkeley: University of California Press.

Streeck, Wolfgang. 2005. The sociology of labor markets and trade unions. In The handbook of economic sociology, ed. N. Smelser and R. Swedberg, 254-283. Princeton: Princeton University Press.

Sun, Jianmin, and Kaifeng Jiang. 2009. An exploratory study on the construct of organizational identification under Chinese context. Sociological Studies 1: 184-216.

Taylor, Frederick W. 1997/1911. The principles of scientific management. New York: Dover Publications.

Tong, Genxing. 2005. The household-employed in north town: daily practice and its political economy. In Sociological master degree papers from three universities, ed. Yefu Zheng, Yuan Shen, and Suiming Pan, 279-335. Jinan: Shandong Renmin Press.

Walder, Andrew G. 1986. Communist neo-traditionalism: work and authority in Chinese industry. Berkeley: University of California Press.

Waldinger, Roger. 1993. The two sides of ethnic entrepreneurship. International Migration Review 27 (3): $692-701$.

Waldinger, Roger, et al. 1990. Ethnic entrepreneurs. Newbury Park: Sage.

Wang, Shuixiong. 2008. The game under structures_combining big sociological inquiry and game analysis. In The logic of behavior in the change of institutions, ed. Shuixiong Wang, 198-256. Beijing: Property Rights Press.

Weber, Max. 1978. In Economy and society: an outline of interpretive sociology, ed. G. Roth and C. Wlttich. Berkeley: University of California Press.

Wen, Xiang, and Xiao Zhou. 2007. The theory of labor process and Chinese experiences: a critical review. Social Sciences in China 3: 29-39.

Yang, Song, Steven Worden, and George Wilson. 2004. Sources of organizational commitment: the effects of internal labor markets and worker values. Sociological Spectrum 24 (6): 667-688.

Zhou, Xiao. 2007. Relational hegemony: repression and resistance in the construction site. In Sociological master degree papers from three universities, ed. Yefu Zheng, Yuan Shen, and Suiming Pan, 382-438. Jinan: Shandong Renmin Press.

Zhu, Ying, and Malcolm Warner. 2000. An emerging model of employment relations in China: a divergent path from the Japanese? International Business Review 9 (3): 345-361.

\section{Submit your manuscript to a SpringerOpen ${ }^{\circ}$ journal and benefit from:}

- Convenient online submission

- Rigorous peer review

- Open access: articles freely available online

- High visibility within the field

- Retaining the copyright to your article 